thus producing a steady powerful flame of beautiful appearance. This porcelain tube forms the lower portion of the chimney, around which is placed the regenerator. The products of combustion, in passing away, heat the regenerator by conduction, through the metal of the same; and the air, passing upwards and downwards between its metallic surfaces, as also indicated by arrows in the diagram, carries the heat back to the flame. The lamp is closed below by a glass globe, which, however, need not be removed for lighting, as a flash-light is provided for that purpose.

These lamps are made of different sizes, with a consumption varying from to to 40 cubic feet of gas per

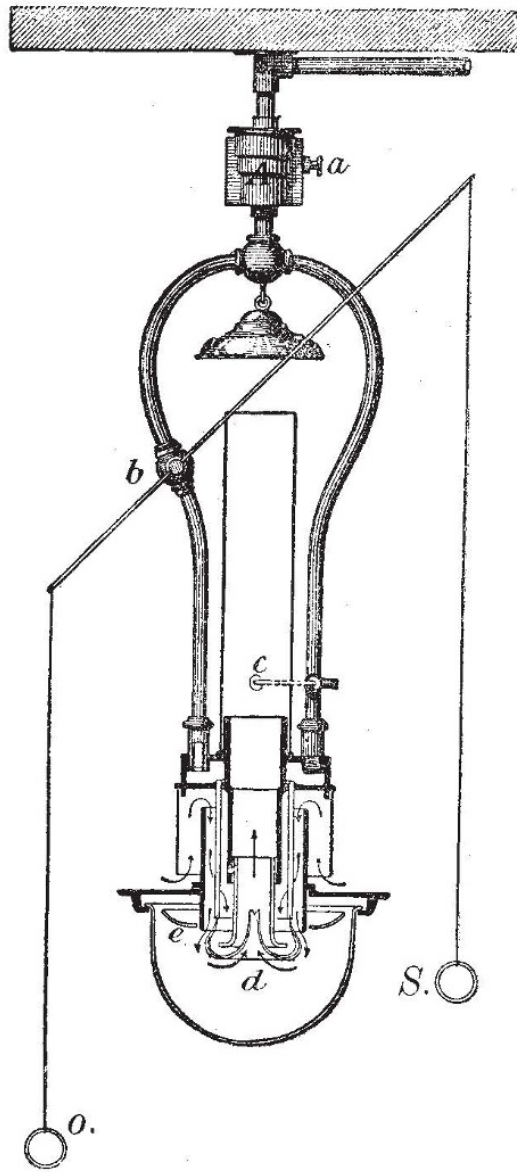

hour ; with London gas they give a light of from ten to twelve candles per cubic foot consumed per hour, which is from four to five times as much as is obtained with ordinary burners. It would have been easy to arrange the lamp we have just described so as to produce a much higher result than that given above; but, to produce this effect, the air supplying the burner would have to be passed through small channels, which would be liable to be partly closed up by oxidation, and thus, by reducing the air-supply, cause the lamp to smoke, whereas the Siemens lamp has been specially designed to provide against this unpleasantness, to which regenerative gaslamps are more or less liable.

\section{HEINRICH GUSTAV REICHENBACH.}

$0 \mathrm{~N}$

$\mathrm{N}$ the 6 th inst., there died at Hamburg, in the sixtyseventh year of his age, a botanist long and familiarly known to his English colleagues, and one whose name will be preserved in the annals of botany.

Heinrich Gustav Reichenbach had been Professor of Botany and Director of the Botanic Garden at Hamburg since 1862 . He was born in Leipzig, his father having been also a well-known botanist and Professor in Dresden from 1820 till his death in 1879 . Much of the younger Reichenbach's work was done in association with his father, with whom he co-operated in the production of the later volumes of the carefully elaborated Icones Flore Germanice et Helvetica. Bit work of this character, carefully and critically executed though it was, was cast into the shade by the magnitude of his labours among the Orchidacex. Reichenbach the younger devoted more than forty years of his life, almost (though, as we have seen, not quite) exclusively to the study of orchids.

At the commencement of his career, Lindley was still in the plenitude of his powers, but when, some quarter of a century since, the great English botanist failed in health, and subsequently died, there was no one to question the supremacy of Reichenbach so far as orchids were concerned.

From that time to the present the Hamburg Professor has reigned with undisputed sway. His reign corresponds in its progress with the development of that passion for the cultivation of orchids which has attained such large proportions in this country. This is a fashion which at present shows no sign of waning here, whilst it is spreading widely in other countries. It has proved of signal service to orchidology in its systematic aspect, and to a less degree to morphology and biology, as witnesses, to cite only one illustration, the work of Darwin on the "Fertilization of Orchids." A hundred years ago about three hundred species were catalogued in the later editions of Linnæus's "Species Plantarum," and those three hundred were very imperfectly known or illustrated. About sixty years have elapsed since Lindley began his first systematic enumeration of the genera and species, a work in which he was at first greatly aided by the previous labours of Brown and by the splendid drawings of Bauer. In 1840 , at the conclusion of the "Genera and Species," Lindley mentions that the total number of species included in that work amounted to I980, of which the author himself had analyzed three-fourths. Later estimates in the "Vegetable Kingdom "bring the numbers up to 394 genera and 3000 species. Bentham, in 1883 , calculated the known species as between 4500 and 5000 ; while Pfitzer, the most recent census-maker, gives the extreme number of species as I0,000. Granting that this latter figure is excessive, it at least suffices to illustrate the enormous increase in our knowledge of orchids. This advance has been, as we have said, chiefly due to the orchidomania which originated as a consequence of the exhibition of a few remarkable forms at the early meetings of the Horticultural Society, and which has been growing ever since. We never heard of any material good arising from the tulipomania; but the passion for orchids, involving, as it has done, the exploration of the countries where they grow, and the collection and transmission of countless thousands of specimens, live and dead, not only of orchids but of plants of other orders also, has most undoubtedly been of great service to botany, and it has served also to illustrate the great, but often unappreciated, value of gardens as instruments of scientific research. Dried specimens of orchids afford a sorry spectacle at best, and the characters upon which the distinction of genera and species depend are readily obliterated or lost in the drying process. But in gardens the material is often ample, and in the best condition for examination.

Reichenbach, as we have seen, was able to avail himself to a much larger extent than any of his fredecessors of the facilities offered by gardens. He became the acknowledged referee on all questions of nomenclature, and to him were constantly submitted fresh specimens for examination. Of late years, also, hybridization has been practised to a large extent among orchids, and the resultant hybrids found their way to Hamburg, there to be 
compared with the parental forms from which they had emanated. The result of this correspondence with orchid-growers of all classes in all countries, as well as with collectors and botanists, was that the Hamburg Professor became the depositary of the greatest amount of orchid-lore yet accumulated, and the possessor of the largest stores of materials relating to the order. Unhappily his synthetic faculty was by no means so strong as his acquisitive tendencies were great and as his analytical powers were developed; so that much is left for his successors to accomplish in collating and expounding his work. In no place in the world can this be done so readily as at Kew, so that on all accounts it is earnestly to be hoped that the late Professor's herbarium and notes may find their way to that establishment, where Lindley's collections are already enshrined.

Reichenbach was almost exclusively a systematist. He had little to say on morphological questions, and less on the biological points which lend such great interest to the study of the order. Speculations were made the subject of sarcasm by him, and to the last it may be doubted whether he had any great amount of sympathy with those researches which have furnished the clue to the explanation of the extraordinary and highly diversified structure of orchid-flowers, and illustrated alike its genetic and its physiological significance. Nevertheless, as in his lifetime he was constantly and disinterestedly at the service alike of his brother naturalists and of the orchidgrowing community, shrinking from no labour or trouble where an orchid was concerned, so in that future reconstruction of the order on morphological and physiological principles which is inevitable, the botanist, be he who he may, will find himself as much indebted to the labours of Reichenbach, as unable to proceed without constant reference to them, as are the students of the present day. $\mathrm{His}$ title to our gratitude is indefeasible; it will be even more so to our successors.

\section{NOTES.}

THe Croonian Lecture, "Les Inoculations Préventives," will be delivered at the Royal Society to-day, by Dr. Roux, of the Pasteur Institute, Paris.

THE ship Hvidjörnen arrived at Copenhagen on May 2I from Greenland, having on board Dr. Fridtjof Nansen and his companions, who succeeded in crossing Greenland from east to west on snow shoes. The members of the expedition received an enthusiastic welcome from a large crowd.

THE anniversary meeting of the Royal Geographical Society, for the election of President, Council, \&c., will be held in the hall of the University of London, Burlington Gardens, on Monday, May 27, at 2.30 p.m., General R. Strachey, F.R.S., C.S.I., President, in the chair. After the presentation of the Royal medals for the encouragement of geographical science and discovery, the annual address on the progress of geography during the year will be delivered by the President.

AN International Congress of Chronometry will be opened at the National Observatory, Paris, on September 7. An influential organizing Committee has been formed, of which ViceAdmiral de Fauque de Jonquières has accepted the presidency. Those who wish to become members should communicate with the secretary, M. E. Caspari.

CONGREgation has approved of the nomination of Dr. William Huggins, F.R.S., as a visitor of the Oxford University Observatory, in place of the late Dr. Warren de la Rue.

AcCording to the Rome Correspondent of the Daily Neres, the Pope has decreed, owing to the wishes expressed by Padre Denza more than a year ago, that the works for the Astronomical
Observatory, to be erected in the Vatican, are to be begun at once. The site selected is the tower over the rooms occupied by the Master of the Sacred College, it being the most elevated building of the Vatican Palace. The cost is estimated at a million of francs.

Mr. W. P. Johnston, Government Electrician, Calcutta, died on April 23, at Darjeeling. According to Allen's Indian Mail, Mr. Johnston had served for over twenty years in the Indian Telegraphs, and had specially distinguished himself in the scientific branch of the Department, his researches in connection with duplex telegraphy, the working of river cables and long stretches of land lines, having been unusually productive of good results. He was also one of the first to improve the telephone after its introduction into India.

IT is reported in the Chinese Press that the Marquis Tsêng, so well known in Europe as the Ambassador of China to this country, has been appointed to the control of the Foreign Science College in Pekin.

Prof. Milne, of the University of Tokio, whose work in connection with the investigation of earthquake phenomena is well known to all readers of this journal, is in England for a short time on leave of absence.

DR. JoHn Gibson, who has for some time been engaged in superintending the physical work of the Fishery Board for Scotland, has recently completed a series of investigations which are likely to throw considerable light on the problems connected with ocean currents. The detailed results will appear in the next Annual Report of the Fishery Board; but from a preliminary note communicated to the Royal Society of Edinburgh it appears that two chemically distinct kinds of sea water are present in the North Sea. The difference between these two waters is rendered perfectly distinct by sufficiently accurate determinations of the relation between chlorine and density, and is not due to river water flowing into the North Sea. Water in which the relative proportion of chlorine is high reaches the North Sea from the surface of the Atlantic, round the north of Scotland and also through the English Channel, while water in which the relative proportion of chlorine is low flows into the North Sea from the north, and has been found on the surface as far north as $79^{\circ}$ N. lat. The determinations of chlorine and density in the samples of ocean water collected during the Challenger Expedition, as published in the Challenger Reports, seem to show that similar differerces of composition exist in ocean waters. To judge from these determinations, the mass of ocean water, especially in southern latitudes, approximates in chemical composition to that flowing as above mentioned into the North Se,a from the surface of the Atlantic. The water in which the rilative proportion of chlorine is less appears to have been met with chiefly to the north of the equator and to the south-west of the principal outlets from the Arctic Ocean. This, as well as its chemical composition, seems to point to an Arctic origin.

A severe earthquake occurred at Plevlje, in Bcsnia, at 3.43 a.m., on May 8. It lasted three seconds, the direction of the shocks being from west to east.

Several shocks of earthquake occurred on April 26 in Schwyz, and at Schaffhausen and Wilchingen.

ON May 20 a waterspout burst over the district of Crimmitz schau, in Saxony. Two persons were drowned at the town of that name, and a third at the neighbouring village of Lauterbach.

The British Consul at San José, in Costa Rica, in his lates report says that a Meteorological Institute has been established at San José, and several useful observations have been taken, especially of recent earthquakes. $\mathrm{He}$ adds that the year I 888 did not have a very propitious closing, for just two days 